\title{
Phylogenetic analysis and immunohematological response associated with two commercially available vaccines against canine distemper and canine parvovirus
}

\author{
Mohamed Nayel ${ }^{a *}$, Ahmed Zaghawa ${ }^{a}$, Attyat Zayed ${ }^{b}$, Ahmed Elsify ${ }^{a}$, Akram Salama ${ }^{a}$, Ahmed Kamr $^{c}$, Walid \\ Mousa ${ }^{a}$, Ali Dawood ${ }^{a}$, Yassien Badr ${ }^{d}$, Hend Altaib ${ }^{e}$, B.E. Hildreth III ${ }^{f}$ \\ ${ }^{a}$ Department of Medicine and Infectious Diseases (Infectious Diseases), Faculty of Veterinary Medicine, University of \\ Sadat City, Egypt \\ ${ }^{\mathrm{b}}$ Pet Animal Vaccine Research Department, Veterinary Serum and Vaccine Research Institute, Egypt \\ c Department of Medicine and Infectious Diseases (Animal Medicine), Faculty of Veterinary Medicine, University of Sadat \\ City, Egypt \\ ${ }^{\mathrm{d}}$ Department of Medicine, Faculty of Veterinary Medicine, Damanhour University, El-Beheira, Egypt \\ e Lab of Genome Microbiology, United Graduate School of Agricultural Science, Gifu University, 1-1 Yanagido, Japan \\ ${ }^{f}$ Department of Biochemistry and Molecular Biology and Hollings Cancer Center, Medical University of South Carolina, USA
}

*Corresponding author: Mohamed Nayel (mohamed.aboalez@vet.usc.edu.eg)

How to cite this article: Nayel. M. et al. Phylogenetic Analysis and Immunohematological Response Associated with Two Commercially Available Vaccines Against Canine Distemper and Canine Parvovirus, Veterinary Medicine and Public Health Journal, 1(1);(2020): 5-14.

DOI: https://doi.org/10.31559/vmph2020.1.1.3

Received Date: 26/10/2019 Accepted Date: 1/12/2019

\begin{abstract}
Canine distemper and parvovirus infections are amongst of the most important infectious diseases of dogs. Recently, the range of reports of vaccinated dogs that developed canine distemper and parvovirus infections have multiplied throughout the world. The goals of this study were to evaluate the immune and hematological responses against canine distemper virus (CDV) and canine parvovirus (CPV) after vaccination using two commercially available vaccines. In addition, the antigenic differences between the vaccine strains of CDV and CPV and the current wild-type strains were analyzed to determine possible relationships between these vaccine strains and recent field outbreaks in vaccinated populations. The immune response of both vaccines was determined using serum neutralization and Dot-ELISA. Specific neutralizing antibodies against canine distemper and parvovirus were present in the sera of dogs three weeks after the initial vaccination for both vaccines. Peak antibody titers were documented from the second month post vaccination. Both vaccines were demonstrated to be safe and stimulate a humoral immune response. Results of serum neutralization test and Dot-ELISA were closely similar and correlated with each other. Genetic variations between strains included in both commercial vaccines and circulating wild-type strains suggest that variant strains are most likely responsible for field outbreaks of CDV and CPV in vaccinated dogs.
\end{abstract}

Keywords: Canine distemper; Canine parvovirus; Commercial vaccine; Immunity; Hematology; Genetic analysis 


\section{Introduction}

Canine distemper virus (CDV) and canine parvovirus (CPV) are associated with high fatality rates in young dogs (Latha et al. 2007; Woldemeskel et al. 2011). Canine distemper is an overwhelming infection that is generally pervasive in many countries (Rikula, 2008). Clinical signs may range from non-visible to severe depending on the dog's immune status and environment and may include mucopurulent nasal and conjunctival discharges, biphasic fever, anorexia, depression, diarrhea, hyperkeratosis of the footpads and the nose, and subsequent neurologic signs (Latha et al. 2007). Canine parvovirus is a highly contagious and devastating viral disease that occurs worldwide (Truyen et al. 2000; Shackelton et al. 2005). Enteritis is the key feature of $\mathrm{CPV}$, where the virus destroys rapidly dividing epithelial cells lining the intestinal tract. Secondary bacterial translocation due to loss of intestinal barrier function leads to abdominal pain, septicemia, and death (Prittie 2004; Woldemeskel et al. 2011).

Prophylaxis through vaccination is the most effective method of preventing CDV and CPV infection in young dogs (Soliman 2014; Day et al. 2016). All vaccines that are currently commercially available for dogs are multivalent vaccines (Rikula 2008). The measurement of antibody titers is considered the only practical method for predicting a protective immune response following vaccination and is considered a valuable indicator to determine if revaccination is needed (Day et al. 2010; Sykes 2014). Serum neutralization and hemagglutination inhibition tests are considered the gold standards for determining protective antibody titers against CDV and CPV (Gray et al. 2012; Litster et al. 2012).

Recently, the number of reports of vaccinated dogs that developed CDV infection with characteristic clinical signs has increased throughout the world (Lan et al. 2006; Kapil et al. 2008; Gamiz et al. 2011; da Fontoura et al. 2014; Zhao et al. 2014; Riley and Wilkes 2015). The CPV-2 vaccine-induced immunity is protective against CPV-2 homologous virus but not against the variants, thus allowing virulent strains to cause infection and even death in regularly vaccinated dogs (Martella et al. 2005; Decaro et al 2008; Miranda and Thompson 2016).

Studies focusing upon the genotypic analysis of vaccine strains included in various commercially available canine vaccines are very rare (Demeter et al. 2007; Ramdas 2011). Vaccine strains genotypic characterization will help in knowing or confirming if there are major antigenic differences between the CDV and CPV vaccine strains and the currently circulating wild-type strains, which may be a possible cause of the field outbreaks in vaccinated populations. Therefore, the aims of this study were to measure the immune and hematological responses of two widely used commercially available canine vaccines and to analyze the potential role of antigenic differences between the CDV and CPV vaccine strains and the currently circulating wild-type strains as a potential cause of the vaccine related diseases in dogs.

\section{Materials and methods}

\section{Animals and vaccination protocols}

Twenty, approximately 10 to 13-weeks-old Thebes Land Dog (Baladi) puppies seronegative to CDV and $\mathrm{CPV}$, were divided into 3 groups. Group A $(n=8)$, puppies were vaccinated with the Nobivac ${ }^{\circledR}$ DHPPI vaccine according to manufacturer's instructions. Group B $(n=8)$, puppies were vaccinated with the Vanguard $^{\circledR}$ plus 5/CV-L vaccine according to manufacturer's instructions. Group $C(n=4)$, control group which was not vaccinated. Vaccinated and control puppies were maintained separately under the same housing conditions and feeding regimen. Animal studies were conducted according to the guidelines of the Committee of Animal Care and Welfare, University of Sadat City (VUSC-011-1-18).

\section{Vaccines}

Commercially available vaccines used in this study were Nobivac $^{\circledR}$ DHPPI vaccine (Schering-Plough Animal Health, New Zealand) and Vanguard ${ }^{\circledR}$ Plus 5/CV-L vaccine (Pfizer Animal Health, Ireland). Nobivac $^{\circledR}$ DHPPI vaccine is composed of a live attenuated freeze-dried CDV, canine adenovirus type 2 (CAV-2), CPV and canine parainfluenza (CPI). Vanguard $^{\circledR}$ Plus 5/CV-L vaccine is composed of a freeze-dried preparation of attenuated strains of CDV, CAV-2, CPV, CPI, and inactivated whole cultures of Leptospira (L)icterohaemorrhagicae, and L. canicola plus a liquid preparation of inactivated canine coronavirus (CCV).

\section{Blood sample collection}

Blood samples were collected by jugular venipuncture into sterile screw-capped vials and centrifuged at $4,000 \times \mathrm{g}$ for 10 minutes at $4^{\circ} \mathrm{C}$. Serum was aliquoted into smaller volumes and stored at $-20^{\circ} \mathrm{C}$ until analysis. Serum samples were obtained before and weekly after vaccination for 7 weeks then monthly up to 8 months post vaccination.

\section{Cell culture and virus titration}

CDV- and CPV-free baby hamster kidney $\left(\mathrm{BHK}_{21}\right)$ and African green monkey kidney (Vero) cell lines were supplied by Veterinary Serum and Vaccine Research Institute (VSVRI, Egypt). $\mathrm{BHK}_{21}$ and Vero cells were used for virus titration and serum neutralization tests (SNT).

Ten-fold serial dilutions of CDV and CPV stock (VSVRI, Egypt) were prepared and inoculated into replicate $\mathrm{BHK}_{21}$ cell cultures in 96-well tissue culture plates. The number of cells that were infected was determined for each virus dilution, mainly by looking for evidence of cell death. The end of the titration was expressed as the dilution of virus at which $50 \%$ of the cells were infected as $50 \%$ infectious dose $\left(\mathrm{ID}_{50}\right)$ per milliliter. Virus titer was expressed as $\log _{10}$ of $50 \%$ tissue culture infectious doses $\left(\log _{10}\right.$ TCID $_{50}$ ) (Reed and Muench 1938).

\section{Serum neutralization test (SNT)}

The SNT was carried out to measure antibody responses to $\mathrm{CDV}$ and $\mathrm{CPV}$ using the microtiter technique as described by (Appel and Robson 1973; Bass et al. 1982; Pratelli et al. 2001; Abdelmagid et al 2004). Briefly, all sera were heat inactivated in a water 
bath at $56^{\circ} \mathrm{C}$ for 30 minutes. Twenty-five micro liters $(\mu \mathrm{l})$ of Hank's balanced salt solution (HBSS) were added to all wells of flat-bottomed 96-well microtiter plates except those in the first raw. (Positive and negative control included). Fifty $\mu$ of the tested sera was added to the individual wells of the first raw then two fold serial dilutions were carried out. Five wells were allocated for each serum dilution. Twenty-five $\mu \mathrm{l}$ of the specific virus (CDV or CPV) containing 100 TCID50 was added to each well of diluted serum sample. The plate was agitated to mix the virus serum mixture and incubated for one hour at $37^{\circ} \mathrm{C}$. Each well of the plates received $150 \mu \mathrm{l}$ of $\mathrm{BHK}_{21}$ cell suspension resuspended with Eagles MEM containing 5\% fetal calf serum containing 1 to $2 \times 10^{4}$ cells $/ 0.1 \mathrm{ml}$ cells. The plates were incubated for 7 days at $37^{\circ} \mathrm{C}$ and daily examined microscopically for the development of the cytopathic effect (CPE). The antibody titer was expressed as the reciprocal of the final serum dilution, which neutralizes and inhibits completely the CPE of 100 TCID50 of the used virus according to (Singh et al 1967).

Dot ELISA assays for detecting antibodies to CDV and CPV

The Dot ELISA assays for CDV and CPV IgG antibodies were carried out using the immunocomb dot ELISA (Biogal Laboratories, Israel) as described by (Waner et al. 1996; Waner et al. 1998). Results were expressed as S units on a scale of 0 to 6 .

\section{Sequence and phylogenetic analysis}

The sequences of $\mathrm{H}$ gene (Canine distemper viruses) and $\mathrm{Vp} 2$ gene (Canine parvoviruses) of Nobivac $^{\circledR}$ DHPPI, Vanguard ${ }^{\circledR}$ Plus $5 / C V-L$ vaccine strains, other vaccines strains and field isolates from different countries were retrieved from the GenBank and aligned using ClustalW algorithms available in the Molecular Evolutionary Genetic Analysis (MEGA version X) software (Kumar et al 2018). The phylogenetic trees were built in MEGA version X using the Neighbor-Joining method (Saitou and Nei 1987). The evolutionary distances were computed using the Jukes-Cantor method. One thousand bootstrap replicates were conducted to assess statistical support for the tree topology. Sequences identity percent were calculated using analysis tool web services from the EMBL-EBI (McWilliam et al. 2013). The potential Nlinked glycosylation sites of the CDV $\mathrm{H}$ protein were determined using the NetNGlyc1.0 server available at the CBS (Center for biological sequence analysis, http://www.cbs.dtu.dk/services/NetNGlyc/).

\section{Hematological examination}

Hematological examination was performed as described previously (Coles, 1986). The total number of erythrocytes per cubic millimeter was determined using physiological saline solution as a diluent and a Neubauer hemocytometer. The total number of leukocytes per cubic millimeter was determined using Turkey's solution as a diluent and a Neubauer hemocytometer. The volume of erythrocytes (PCV) was determined after centrifuging whole blood at $3000 \mathrm{rpm}$ using centrifuge-graduated tubes. Hemoglobin ( $\mathrm{Hb})$ was measured colorimetrically using an $\mathrm{Hb}$ kit (Egyptian company for biotechnology). Giemsa-stained blood films were examined and differential leukocytic counts performed using the cross-sectional method (Schalm et al. 1975).

\section{Statistical analysis}

All values are expressed as mean \pm standard error of the mean (SEM). Data normality was assessed using the Shapiro-Wilk statistic and D'Agostino-Pearson omnibus test, of which all data were normally distributed. Therefore, parametric one-way ANOVAs and Duncan post-hoc tests were used to determine if significant differences existed between experimental groups. All procedures were performed using statistical analysis software (SPSS Version 16.0; SPSS Inc., Chicago, USA). Statistical significance was set at $P$ $<0.05$ (Ilstrup 1990). The correlation between the mean serum neutralization titers and the Dot-ELISA results, expressed in $\mathrm{S}$ units, was assessed by using Pearson's correlation coefficient (r).

\section{Results \\ Humoral immune response}

No statistically significant differences existed in antibody titers for CDV and CPV between Nobivac ${ }^{\circledR}$ and Vanguard ${ }^{\circledR}$ vaccines along the duration of the study ( $P$ $>0.05$, Table 1). The results of the dot ELISA and the SNT techniques for IgG of CDV and CPV showed a good correlation between the two techniques for the IgG titers of both CDV and CPV $(\mathrm{P}<0.0001)$ and about 90 percent confidence limits between the SNT titers (as their mean values) and the $S$ values for the IgG of CDV and CPV, respectively. Table 2 shows the Pearson's correlation coefficients for the relationships between SNT and Dot-ELISA.

\section{Nucleotide (nt) and amino acid (aa) sequence alignment} of CDV

Nobivac ${ }^{\circledR} \quad$ CDV vaccine strain (strain Onderstepoort) $\mathrm{H}$ gene sequence is 1815 bp length, encoding for 604 amino acids; while Vanguard ${ }^{\circledR}$ CDV vaccine strain (strain $\mathrm{N}-\mathrm{CDV}$ ) $\mathrm{H}$ gene is $1824 \mathrm{bp}$ length, encoding for 607 amino acids. Genetic identity percentages between Nobivac ${ }^{\circledR}$ and Vanguard ${ }^{\circledR}$ CDV vaccine strains to the most frequently used vaccine strains are summarized in Table 3.

By further FASTA (DNA and protein sequence alignment software) analysis, Vanguard ${ }^{\circledR}$ CDV vaccine strain had the highest identity (99.78\% nt, 99.51\% aa) to virus Rockborn-46th laboratory strain, followed by (99.73 nt, 99.34 aa) to the vaccine virus RockbornCandur and (99.34 nt, 98.68 aa) to a Lesser Panda (Ailurus fulgens) in China (AF178039). Genetic identity percentages between Nobivac ${ }^{\circledR}$ and Vanguard ${ }^{\circledR}$ $\mathrm{CDV}$ vaccine strains to the field isolates from different localities were summarized in Table 4.

Nobivac $^{\circledR}$ CDV vaccine strain showed 6 potential glycosylation sites for asparagine N-linked glycosylation at positions 19-21, 149-151, 391-393, 422-424, 456-458 and 587-589. Vanguard ${ }^{\circledR}$ CDV vaccine strain showed 7 potential glycosylation sites for asparagine $\mathrm{N}$-linked glycosylation at positions 19 21, 149-151, 309-311, 391-393, 422-424, 456-458, and 603-605. Concerning field isolates, ten potential glycosylation sites for asparagine N-linked 
Glycosylation were Mfound at amino acid positions 19-21, 126-128, 149-151, 309-311, 391-393, 422-424,

\begin{tabular}{|c|c|c|c|c|}
\hline \multirow{2}{*}{$\begin{array}{l}\text { Time of sera } \\
\text { collection }\end{array}$} & \multicolumn{2}{|c|}{$\mathrm{CDV}$} & \multicolumn{2}{|c|}{$\mathrm{CPV}$} \\
\hline & Nobivac $^{\circledR}$ & Vanguard $^{\circledR}$ & Nobivac $^{\circledR}$ & Vanguard $^{\circledR}$ \\
\hline Day 0 & $<2^{a}$ & $<2^{a}$ & $<2^{a}$ & $<2^{a}$ \\
\hline 3 weeks & $13.45 \pm 1.12^{\mathrm{a}}$ & $12.34 \pm 1.14^{\mathrm{a}}$ & $13.45 \pm 1.12^{\mathrm{a}}$ & $12.34 \pm 1.14^{\mathrm{a}}$ \\
\hline 4 weeks & $29.34 \pm 1.17^{a}$ & $26.91 \pm 1.12^{\mathrm{a}}$ & $26.91 \pm 1.12^{\mathrm{a}}$ & $29.34 \pm 1.17^{a}$ \\
\hline 5 weeks & $34.90 \pm 1.23^{\mathrm{a}}$ & $41.50 \pm 1.14^{\mathrm{a}}$ & $49.35 \pm 1.14^{a}$ & $53.82 \pm 1.12^{\mathrm{a}}$ \\
\hline 6 weeks & $53.82 \pm 1.12^{\mathrm{a}}$ & $64.00 \pm 1.00^{\mathrm{a}}$ & $98.70 \pm 1.14^{a}$ & $107.63 \pm 1.12^{\mathrm{a}}$ \\
\hline 7 weeks & $107.63 \pm 1.19^{a}$ & $98.70 \pm 1.14^{\mathrm{a}}$ & $152.22 \pm 1.12^{\mathrm{a}}$ & $152.22 \pm 1.19^{a}$ \\
\hline 2 months & $166.00 \pm 1.14^{\mathrm{a}}$ & $152.22 \pm 1.12^{\mathrm{a}}$ & $166.00 \pm 1.20^{\mathrm{a}}$ & $166.00 \pm 1.14^{a}$ \\
\hline 3 months & $166.00 \pm 1.20^{\mathrm{a}}$ & $152.22 \pm 1.19^{a}$ & $166.00 \pm 1.14^{\mathrm{a}}$ & $152.22 \pm 1.29^{a}$ \\
\hline 4 months & $181.02 \pm 1.14^{\mathrm{a}}$ & $166.00 \pm 1.14^{\mathrm{a}}$ & $152.22 \pm 1.29^{a}$ & $166.00 \pm 1.20^{\mathrm{a}}$ \\
\hline 5 months & $166.00 \pm 1.20^{\mathrm{a}}$ & $166.00 \pm 1.14^{\mathrm{a}}$ & $166.00 \pm 1.14^{\mathrm{a}}$ & $139.58 \pm 1.39^{a}$ \\
\hline 6 months & $166.00 \pm 1.14^{\mathrm{a}}$ & $152.22 \pm 1.12^{\mathrm{a}}$ & $152.22 \pm 1.19^{a}$ & $152.22 \pm 1.19^{a}$ \\
\hline 7 months & $161.27 \pm 1.16^{\mathrm{a}}$ & $156.03 \pm 1.14^{\mathrm{a}}$ & $161.27 \pm 1.16^{\mathrm{a}}$ & $172.28 \pm 1.15^{\mathrm{a}}$ \\
\hline 8 months & $128.00 \pm 1.20^{\mathrm{a}}$ & $105.00 \pm 1.14^{\mathrm{a}}$ & $128.00 \pm 1.20^{\mathrm{a}}$ & $128.00 \pm 1.16^{\mathrm{a}}$ \\
\hline
\end{tabular}

\begin{tabular}{|c|c|c|}
\hline \multicolumn{3}{|c|}{$\begin{array}{l}\text { Table (2): Pearson's correlation coefficients (r) for the relationships between } \\
\text { the results of Dot ELISA and SN antibody tests for canine distemper virus } \\
\text { (CDV) and canine parvovirus (CPV) immunoglobulin G (lg G). }\end{array}$} \\
\hline Parameter & $\mathrm{R}^{2}$ & P value (two-tailed) \\
\hline Nobivac $^{\circledR} \mathrm{CDV}$ antibody titer & 0.9055 & $<0.0001$ \\
\hline Vanguard ${ }^{\circledR} \mathrm{CDV}$ antibody titer & 0.8801 & $<0.0001$ \\
\hline Nobivac ${ }^{\circledR}$ CPV antibody titer & 0.9211 & $<0.0001$ \\
\hline Vanguard ${ }^{\circledR} \mathrm{CPV}$ antibody titer & 0.8917 & $<0.0001$ \\
\hline
\end{tabular}

\begin{tabular}{|c|c|c|c|c|}
\hline Vaccines & Onderstepoort & Snyder Hill & Lederle & Convac \\
\hline Nobivac $^{\circledR}$ & $98.95 \mathrm{nt}, 97.68$ аa & $97.02 \mathrm{nt}, 95.70 \mathrm{aa}$ & $99.39 \mathrm{nt}, 98.84 \mathrm{aa}$ & $98.62 \mathrm{nt}, 97.35$ aа \\
\hline Vanguard $^{\circledR}$ & $92.76 \mathrm{nt}, 90.73 \mathrm{aa}$ & $92.93 \mathrm{nt}, 92.09 \mathrm{aa}$ & $93.04 \mathrm{nt}, 91.56 \mathrm{aa}$ & $93.09 \mathrm{nt}, 91.27 \mathrm{aa}$ \\
\hline
\end{tabular}

456-458, 584-586, 587-589 and 603-605. Field isolates showed from 6 positions as minimum to 9 positions as maximum with positions 19-21, 149-151, 309-311, 391-393, 422-424, 456-458, 587-589 and 603-605 most frequently recorded.

By phylogenetic analysis, using CDV strains from various CDV lineages, Nobivac ${ }^{\circledR}$ CDV vaccine strain was shown to be genetically related to America-1 vaccine strains (Fig. 1). Vanguard ${ }^{\circledR}$ CDV vaccine strain was shown to be genetically related to America- 2 viruses and indistinctly related to America-1 CDVs (Fig. 1).

Nucleotide and amino acid sequence alignment of CPV

Nobivac $^{\circledR}$ strain C154 and Vanguard ${ }^{\circledR}$ strain NL35-D are both CPV-2 strains of 1755 bp length and 584 amino acids. Their identity percent with a reference CPV-2 and its variants are summarized in Table 5.

By further FASTA analysis, Nobivac ${ }^{\circledR} \mathrm{C} 154$ and Vanguard ${ }^{\circledR}$ NL-35-D as CPV-2 differ from CPV-2 a (GU380298.1), CPV-2 b (FJ005263.1), CPV-2 c (FJ222821.1) variants in $4 \mathrm{nt}$ at positions 259 (T-A), 302 (T-C), 899 (C-G), 913 (G-T) and their corresponding amino acids ( $87 \mathrm{M}-\mathrm{L}, 101 \mathrm{I}-\mathrm{T}, 300 \mathrm{~A}-\mathrm{G}$, $305 \mathrm{D}-\mathrm{Y}$ ). Residue 426 has $\mathrm{N}$ in case of CPV-2 and CPV- 2a, D in case of CPV-2b and $\mathrm{E}$ in case of CPV-2c (Table 6).

By phylogenetic analysis, using representatives of CPV variants, Nobivac ${ }^{\circledR}$ C154 and Vanguard ${ }^{\circledR}$ NL-35-D were shown to be genetically related to CPV-2 (Fig. 2). Effects of Nobivac ${ }^{\circledR}$ and Vanguard ${ }^{\circledR}$ on blood parameters

Red blood cell (RBCs) count, packed cell volume (PCV), and $\mathrm{Hb}$ concentrations were not significantly different between Nobivac ${ }^{\circledR}$ and Vanguard ${ }^{\circledR}$ vaccinated groups when compared to controls for the duration of the experiment $(P>0.05)$. White blood cell (WBCs) count was not statistically different in Nobivac $^{\circledR}$ and Vanguard $^{\circledR}$ vaccinated dogs when compared with controls on day $0(P>0.05)$; however, there was a significant increase in WBC count after both vaccines when compared with controls at all examined time points post-vaccination $(P<0.05)$. There was no difference in both lymphocyte and neutrophil counts in Nobivac $^{\circledR}$ and $\operatorname{Vanguard}^{\circledR}$ vaccinated dogs when compared with controls on day $0(P>0.05)$; however, there was a significant increase in both lymphocyte and neutrophil counts in both vaccinated groups when 
compared to the control group at all examined time points after vaccination $(P<0.05)$.

\begin{tabular}{|c|c|c|c|c|c|c|}
\hline Vaccines & $\begin{array}{l}\text { China } \\
\text { (AF178039) }\end{array}$ & $\begin{array}{l}\text { Germany } \\
\text { (AY386315.1) }\end{array}$ & $\begin{array}{l}\text { Uruguay } \\
\text { (KM280689.1) }\end{array}$ & $\begin{array}{l}\text { South Africa } \\
\text { (KY971528.1) }\end{array}$ & $\begin{array}{l}\text { USA } \\
\text { (AY964110.1) }\end{array}$ & $\begin{array}{l}\text { Taiwan } \\
\text { (DQ191175.1) }\end{array}$ \\
\hline Nobivac $^{\circledR}$ & $\begin{array}{l}93.06 \% \mathrm{nt}, \\
92.39 \% \mathrm{aa}\end{array}$ & $\begin{array}{l}92.78 \% \text { nt, } \\
91.58 \% \text { aа }\end{array}$ & $\begin{array}{l}\text { 92.51\%nt, } \\
91.91 \% \text { aа }\end{array}$ & $\begin{array}{l}92.12 \% \text { nt, } \\
90.92 \% \text { aа }\end{array}$ & $\begin{array}{l}91.46 \% \\
91.09 \% \text { аa }\end{array}$ & $\begin{array}{l}91.57 \% \mathrm{nt}, \\
90.59 \% \mathrm{aa}\end{array}$ \\
\hline Vanguard ${ }^{\circledR}$ & $\begin{array}{l}99.34 \% \mathrm{nt}, \\
98.68 \% \mathrm{aa}\end{array}$ & $\begin{array}{l}97.75 \% \mathrm{nt}, \\
96.71 \mathrm{aa}\end{array}$ & $\begin{array}{l}97.04 \% \mathrm{nt}, \\
96.05 \% \mathrm{aa}\end{array}$ & $\begin{array}{l}96.05 \% \mathrm{nt}, \\
95.06 \% \mathrm{aa}\end{array}$ & $\begin{array}{l}95.89 \% \text { nt, } \\
95.72 \% \text { aа }\end{array}$ & $\begin{array}{l}95.72 \% \text { nt, } \\
95.72 \% \text { aа }\end{array}$ \\
\hline
\end{tabular}

nt, Nucleotides; aa, Amino acids

\begin{tabular}{|c|c|c|c|c|}
\hline Vaccines & CPV-2 (M38245.1) & CPV-2a (GU380298.1) & CPV-2b (FJ005263.1) & CPV-2c (FJ222821.1) \\
\hline Nobivac $^{\circledR}$ & $99.6 \%$ nt, $99.49 \%$ aa & $98.75 \%$ nt, $97.95 \%$ aa & $99.15 \%$ nt, $98.12 \%$ aa & $99.15 \%$ nt, $98.29 \%$ aa \\
\hline Vanguard ${ }^{\circledR}$ & $99.54 \% \mathrm{nt}, 98.97 \%$ аа & $98.88 \%$ nt, $97.77 \%$ aа & $99.20 \% \mathrm{nt}, 97.95 \%$ aа & $99.20 \%$ nt, $98.12 \%$ аa \\
\hline
\end{tabular}

\begin{tabular}{|c|c|c|c|c|c|}
\hline \multicolumn{6}{|c|}{$\begin{array}{l}\text { Table (6): Important amino acids substitutions between } \\
\text { Nobivac }{ }^{\circledR} \text { and Vanguard }{ }^{\circledR} \text { vaccine strains with CPV-2 variants. }\end{array}$} \\
\hline \multirow[t]{2}{*}{ Strain } & \multicolumn{5}{|c|}{ Amino acids residues } \\
\hline & 87 & 101 & 300 & 305 & 426 \\
\hline Nobivac $^{\circledR}$ C154 & M & I & A & $\mathrm{D}$ & $\mathrm{N}$ \\
\hline Vanguard ${ }^{\circledR}$ NL-35-D & M & I & A & D & $\mathrm{N}$ \\
\hline CPV-2 a (GU380298.1) & $\mathrm{L}$ & $\mathrm{T}$ & G & Y & $\mathrm{N}$ \\
\hline CPV-2 b (FJ005263.1) & $\mathrm{L}$ & $\mathrm{T}$ & G & Y & $\mathrm{D}$ \\
\hline CPV-2 c (F/222821.1) & $\mathrm{L}$ & $\mathrm{T}$ & G & Y & $\mathrm{E}$ \\
\hline
\end{tabular}

$\mathrm{M}$, methionine; I, isoleucine; $\mathrm{A}$, alanine; $\mathrm{D}$, aspartic acid; $\mathrm{N}$, asparagine; $\mathrm{L}$, leucine; $\mathrm{T}$, threonine; G, glycine; $Y$, tyrosine; E, glutamic acid.

\section{Discussion}

CDV and CPV vaccine-related disease in dogs has been described in several reports (Hartley 1974; Bestetti et al. 1978; Krakowka et al. 1982; Cornwell et al. 1988; McCandlish et al. 1992; Gloyd 1995). Dogs immunized with Vanguard ${ }^{\circledR}$ vaccines developed canine distemper (McInnes et al. 1992; Pardo et al. 2005). In addition, Onderstepoort-like CDVs vaccines have been recognized in wildlife animals' outbreaks in the United States and have been described infrequently in dogs from Ireland, Korea and Poland (Harder and Osterhaus 1997; Rzeżutka and Mizak 2003; Lednicky et al. 2004; Keawcharoen et al. 2005). In case of CPV, outbreaks of disease caused by CPV-2c in adult dogs that had been vaccinated ideally with a CPV-2 vaccine have been reported (Decaro et al. 2008). The present study was designed to evaluate the immune response of dogs vaccinated with two commercial canine vaccines against CDV and CPV, which are both currently used in clinical veterinary medicine (Nobivac ${ }^{\circledR}$ DHPPI and Vanguard ${ }^{\circledR}$ plus $5 / \mathrm{CV}$-L vaccines). In addition, investigating the antigenic differences between the $\mathrm{CDV}$ and $\mathrm{CPV}$ vaccine strains and the currently circulating wild-type strains as a probable cause of the vaccine related diseases in dogs was carried out. In summary, the results in this study suggest that both Nobivac $^{\circledR}$ and Vanguard ${ }^{\circledR}$ vaccines have the ability to enhance humoral immunity whereby they reach peak antibody response from the second month post vaccination. These results are similar to previous studies (Abdelmagid et al. 2004; Bergman et al. 2006).

The Dot-ELISA CDV/CPV test is a useful, in-clinic ELISA to determine CDV and CPV antibody status (Litster et al 2012). Dot-ELISA screening test is a simple, rapid, and sensitive method for the routine evaluation of antibody titers for CDV and CPV in dogs
(Coyne et al 2001; Ramadass and Latha 2001; Waner et al 2003). The results of the current study have shown a good correlation between the results of the SNT and the dot ELISA for both CDV and CPV IgG antibodies. Our results for IgG antibodies agreed with previous report in which the dot ELISA IgG antibodies levels of CDV and CPV were compared with the serum neutralization tests (Waner et al 1998), hemagglutination inhibition test (Waner et al. 1996) and the immunofluorescence assay (Waner et al. 2003).

The genetic analyses have shown that Nobivac ${ }^{\circledR}$ CDV strain is genetically related to America-1 lineage vaccine group while, Vanguard ${ }^{\circledR} \mathrm{CDV}$ is more closely related to Rockborn-Candur vaccine strain, a wild-type virus strain isolated from a lesser panda (AF178039) in China, and other wild-type strains genetically related to America-2. These findings are supported by many previous reports (Pardo et al. 2005; Uema et al. 2005; Demeter et al 2007; Martella et al. 2011).

The current study obviously shows the dissimilar genetic relationships of Nobivac ${ }^{\circledR} \mathrm{CDV}$ vaccine strain as one of Onderstepoort-like CDVs vaccines from field strains of CDV around the world and this could be one of the causes for CDV vaccination failure ( $\mathrm{Li}$ et al. 2014).

Conversely, Vanguard ${ }^{\circledR}$ CDV vaccine strain was found to be closer genetically to field strains of CDV around the world and even match (nearly 100\% nt) the sequence (AF178039) of Lesser Panda (Ailurus fulgens) from China. Such high genetic identity between Rockborn like CDV vaccines and wild isolates of CDV is widely consistent with the residual virulence of vaccine strains hypothesis (Hartley 1974; Bestetti et al. 1978; Cornwell et al. 1988; Gloyd 1995; Martella et al. 2005). 
Comparing potential N-glycosylation of the CDV H interest as changes in potential $\mathrm{N}$-glycosylation of the CDV $\mathrm{H}$ protein may result in variation in antibody seven potential sites in the vaccine strains (Swati et al 2015). Nobivac ${ }^{\circledR}$ and Vanguard ${ }^{\circledR}$ showed 6 and 7 potential glycosylation sites for asparagine $\mathrm{N}$-linked glycosylation respectively. N-linked glycosylation in case of viruses has a potential role in its virulence and immune interaction properties (Vigerust and Shepherd 2007). Seven to nine N-linked glycosylation sites have been reported in wild CDV strains of which amino acids positions 309-311 in $\mathrm{H}$ protein, is reported to be specific for virulent strains of CDV (Bolt et al. 1997; Iwatsuki et al. 1997). This glycosylation site was also present in Vanguard ${ }^{\circledR}$ CDV strain. Some reports assumed that the variations in $\mathrm{H}$ protein glycosylation played a critical role in the antigenic differences and increase in $\mathrm{N}$ glycosylation can cause vaccine failure (Iwatsuki et al. 1997; Zhao et al. 2008).

There were several amino acids mutations within the VP2 sequence of Nobivac ${ }^{\circledR}$ and Vanguard ${ }^{\circledR}$ CPV vaccine strains in comparison with the three references variants, in particular M87L, I101T, A300G, D305Y. As well as, mutation located in residue 426, which entailed the switches, $(A)$ asparagine $\left(\mathrm{Nobivac}^{\circledR}\right.$ and Vanguard ${ }^{\circledR}$ as CPV-2 and CPV-2a), (D) aspartic acid (CPV-2b), and (E) glutamic acid (CPV-2c). Evolutionary modifications within the CPV-2 genome occurred from the time when CPV-2 appeared in 1978 (Appel et al. 1979), generating the emergence of CPV-2 variants, which includes structural amino acids substitutions in the capsid of the virus resulting in biological and antigenic modifications for each variant to be considered in immunity and natural infections protein between vaccine and wild strains is a point of neutralization (Harder et al. 1996a; Harder et al. 1996b; Iwatsuki et al. 1997). Usually, there are four to (Carmichael 2005).

Changes in the hematologic parameters can be diagnostic and/or an indicator of disease in both humans and animals (Feldman et al. 2000; Salem \& Farag 2014; Willesen et al. 2009). There was no difference in this report in RBC and Hb values between Nobivac $^{\circledR}$ and Vanguard ${ }^{\circledR}$ vaccinated dogs and the control group for the duration of the experiment. These results agreed with (Marinho et al. 2012), who reported that no hematological changes or effect on health status have been observed in puppies vaccinated with attenuated $C D V$ and $C P V$ vaccines.

Evaluation of the leukogram following vaccination revealed that there was no difference in WBC counts, lymphocytes, and neutrophils in Nobivac $^{\circledR}$ and Vanguard ${ }^{\circledR}$ vaccinated dogs when compared with controls on day 0 . However, there was a significant increase in WBCs, lymphocytes, and neutrophils following vaccination in both groups when compared with controls. Our findings are in accordance with a previous study where there was a significant increase in peripheral WBCs in dogs vaccinated with polyvalent vaccines against CDV and CPV (Strasser et al. 2003). On the other hand, Phillips and Schultz (1987) and Miyamoto et al. (1992) reported no change or rather a decrease in WBC and lymphocyte counts one week after immunization with monovalent vaccines or virulent CPV. These differences might originate because of the continuous challenge of the immune system due to replication of polyvalent vaccine viruses.

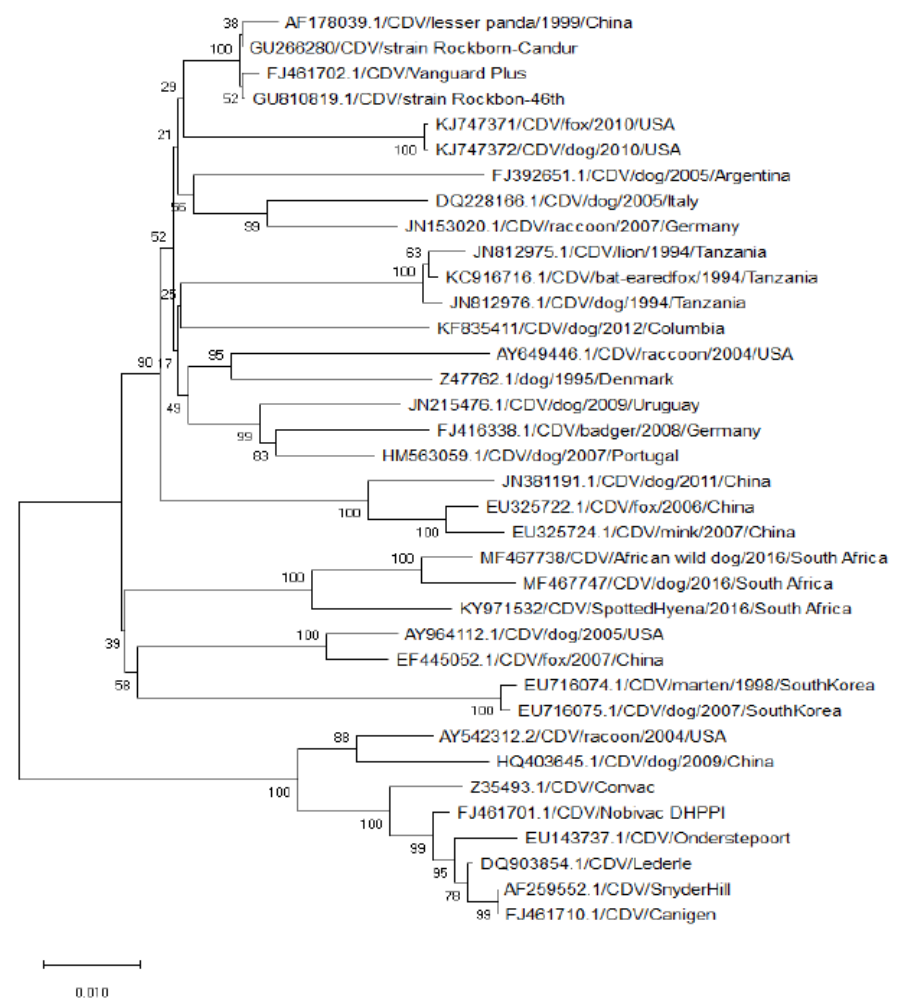

Fig (1): Phylogenetic tree based on the full-length $\mathrm{H}$ gene displaying the genetic relationships between CDV vaccine strains and a selection of wild CDV strains of various genotypes. 

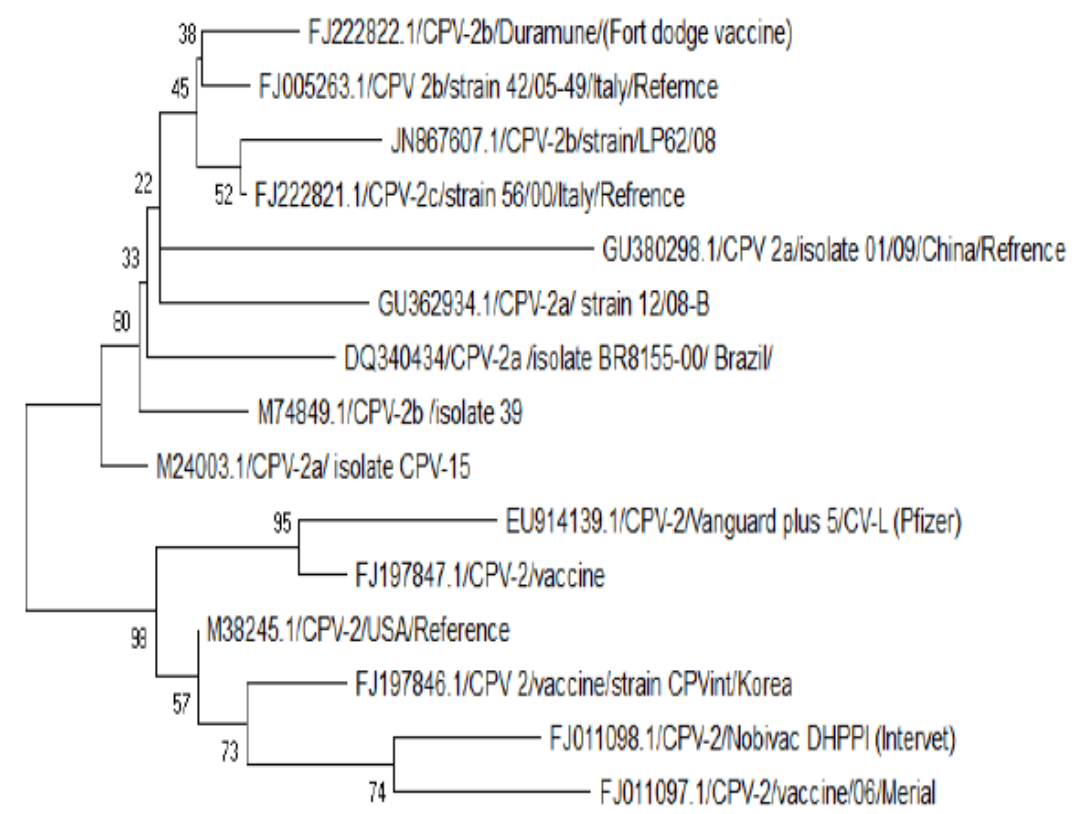

a0010

Fig (2): Phylogenetic tree based on the full-length VP2 gene displaying the genetic relationships between the vaccine strains ad a selection of CPV-2 variants strains.

\section{Conclusions}

In this study, we can conclude that there are no significant differences in the humoral response between both commercially available canine vaccines (Nobivac $^{\circledR}$ and Vanguard ${ }^{\circledR}$ ). Both vaccines induced good levels of immunity. Genetic dissimilarities between Onderstepoort-like vaccines (Nobivac ${ }^{\circledR}$ ) and circulating wild-type strains and virulence residue of Rockborn-like vaccines $\quad\left(\right.$ Vanguard ${ }^{\circledR}$ ) have a contributory role in CDV field outbreaks in vaccinated dogs. Genetic variations between CPV-2 included in both commercial vaccines and its variants circulating in the field nowadays, stand behind CPV field outbreaks in vaccinated dogs. Antigenic matches between the canine polyvalent commercial vaccines and the circulating wild-type strains should be considered necessary for the efficacy of the vaccination process and to overcome post vaccinal disease.

\section{Conflict of interest}

None of the authors of this paper has a financial or personal relationship with other people or organizations that could inappropriately influence or bias the content of the paper. This research did not receive any specific grant from funding agencies in the public, commercial, or not-for-profit sectors.

\section{Acknowledgment}

The authors would like to acknowledge the staff in the VSVRI Pet Animal Vaccine Research Department for their technical assistance.
Note

Refaad and VMPHJ remain neutral with regard to jurisdictional claims in published institutional affiliation.

\section{References}

[1] Abdelmagid. OY., Larson. L., Payne. L., Tubbs. A., Wasmoen. T. \& Schultz. R., Evaluation of the efficacy and duration of immunity of a canine combination vaccine against virulent parvovirus, infectious canine hepatitis virus, and distemper virus experimental challenges, Vet Ther , 5(3)(2004), 173-86.

[2] Appel. M. \& Robson. DS., A microneutralization test for canine distemper virus, Am J Vet Res, 34(11)(1973), 1459-63.

[3] Appel. MJ., Cooper. BJ., Greisen. H., Scott. F. \& Carmichael. LE., Canine viral enteritis. I. Status report on corona- and parvo-like viral enteritides, Cornell Vet, 69(3)(1979), 123-33.

[4] Bass. EP., Gill. MA. \& Beckenhauer. WH., Development of a modified live, canine origin parvovirus vaccine, $J \mathrm{Am}$ Vet Med Assoc, 181(9)(1982), 909-13.

[5] Bergman. JG., Muniz. M., Sutton. D., Fensome. R., Ling. F. \& Paul. G., Comparative trial of the canine parvovirus, canine distemper virus and canine adenovirus type 2 fractions of two commercially available modified live vaccines, Vet Rec, 159(22)(2006), https://doi.org/10.1136/vr.159.22.733

733-736

[6] Bestetti. G, Fatzer. R. \& Frankhauser. R., Encephalitis following vaccination against distemper and infectious hepatitis in the dog. An 
optical and ultrastructural study, Acta Neuropathol, 43(1-2)(1978), 69-75, https://doi.org/10.1007/bf00685000

[7] Bolt. G, Jensen. TD, Gottschalck. E, Arctander. P, Appel. MJ, Buckland. R. \& Blixenkrone-Moller. M., Genetic diversity of the attachment $(\mathrm{H})$ protein gene of current field isolates of canine distemper virus, J Gen Virol, 78(2)(1997), 367-372, https://doi.org/10.1099/0022-1317-78-2-367

[8] Carmichael. LE., An annotated historical account of canine parvovirus, $J$ Vet Med B Infect Dis Vet Public Health, 52(7-8)(2005), 303-311, https://doi.org/10.1111/j.1439-0450.2005.00868.x

[9] Coles. EH., Veterinary clinical pathology, Philadelphia, Pa.: Saunders, (1986)

[10] Cornwell. HJ, Thompson. H, McCandlish. IA, Macartney. L. \& Nash. AS., Encephalitis in dogs associated with a batch of canine distemper (Rockborn) vaccine, Vet Rec, 122(3)(1988), 5459, https://doi.org/10.1136/vr.122.3.54

[11] Coyne. MJ., Burr. JH., Yule. TD., Harding. MJ., Tresnan. DB. \& McGavin. D., Duration of immunity in dogs after vaccination or naturally acquired infection, Vet Rec, 149(17)(2001), 509-515, https://doi.org/10.1136/vr.149.17.509

[12] da Fontoura. B., Renata Pinto. LD., Weber. MN., Caldart. ET., Alves. CDBT., Martella. V., Ikuta. N., Lunge. VR. \& Canal. CW., Genotyping of canine distemper virus strains circulating in Brazil from 2008 to 2012, Virus research, 180(2014), 76-83, https://doi.org/10.1016/j.virusres.2013.12.024

[13] Day. MJ., Horzinek. MC. \& Schultz. RD., WSAVA guidelines for the vaccination of dogs and cats, $J$ Small Anim Pract, 51(6)(2010),1-32, https://doi.org/10.1111/j.1748-5827.2010.00959a.x

[14] Day. M., Horzinek. M., Schultz. R., Squires. R., WSAVA Guidelines for the vaccination of dogs and cats, Journal of Small Animal Practice, 57(1)(2016), https://doi.org/10.1111/jsap.12431

[15] Decaro. N., Desario. C., Elia. G., Martella. V., Mari. V., Lavazza. A., Nardi. M. \& Buonavoglia. C., Evidence for immunisation failure in vaccinated adult dogs infected with canine parvovirus type 2c, New Microbiol, 31(1)(2008), 125-30.

[16] Demeter. Z., Lakatos. B., Palade. EA., Kozma. T., Forgach. P. \& Rusvai. M., Genetic diversity of Hungarian canine distemper virus strains, Vet Microbiol, 122(3-4)(2007), 258-69, https://doi.org/10.1016/j.vetmic.2007.02.001

[17] Feldman. BF., Zinkl. JG., Jain .NC. \& Schalm. OW., Schalm's veterinary hematology, Philadelphia: Lippincott Williams \& Wilkins, (2000)

[18] Gamiz. C., Martella. V., Ulloa. R., Fajardo. R., Quijano-Hernandez. I. \& Martinez. S., Identification of a new genotype of canine distemper virus circulating in America, Vet Res Commun, $\quad 35(6)(2011)$ : https://doi.org/10.1007/s11259-011-9486-6

[19] Gloyd. J., Vaccines recalled, J Am Vet Med Assoc, 207(1995), 1397.

[20] Gray. LK., Crawford. PC., Levy. JK. \& Dubovi. EJ., Comparison of two assays for detection of antibodies against canine parvovirus and canine distemper virus in dogs admitted to a Florida animal shelter, $J \mathrm{Am}$ Vet Med Assoc, 240(9)(2012), 1084-1087, https://doi.org/10.2460/javma.240.9.1084

[21] Harder. TC., Kenter. M., Vos. H., Siebelink. K., Huisman. W., van Amerongen. G., Orvell. C., Barrett. T., Appel. MJ. \& Osterhaus. AD., Canine distemper virus from diseased large felids: biological properties and phylogenetic relationships, J Gen Virol, 77(3)(1996a), 397-405, https://doi.org/10.1099/0022-1317-77-3-397

[22] Harder. TC., Kenter. M., Vos. H., Siebelink. K., Huisman. W., van Amerongen. G., Orvell. C., Barrett. T., Appel. MJ. \& Osterhaus. AD., Canine distemper virus from diseased large felids: biological properties and phylogenetic relationships, J Gen Virol, 77 (3)(1996b), $397-$ 405.

[23] Harder. TC. \& Osterhaus. ADME., Canine distemper virus- A morbillivirus in search of new hosts?, Trends in Microbiology, 5(3)(1997), 120124, https://doi.org/10.1016/s0966-842x(97)01010$\mathrm{x}$

[24] Hartley. WJ., A post-vaccinal inclusion body encephalitis in dogs, Vet Pathol, 11(4)(1974), 301-312, https://doi.org/10.1177/030098587401100403

[25] Ilstrup. DM., Statistical methods in microbiology, Clin Microbiol Rev, 3(3)(1990), 219-26, https://doi.org/10.1128/cmr.3.3.219-226.1990

[26] Iwatsuki. K., Miyashita. N., Yoshida. E., Gemma. T., Shin. YS., Mori. T., Hirayama. N., Kai. C. \& Mikami. T., Molecular and phylogenetic analyses of the haemagglutinin $(\mathrm{H})$ proteins of field isolates of canine distemper virus from naturally infected dogs, J Gen Virol, 78(2)(1997), 373-380, https://doi.org/10.1099/0022-1317-78-2-373

[27] Kapil. S., Allison. RW., Johnston. L., Murray. BL., Holland S, Meinkoth. J. \& Johnson. B., Canine distemper virus strains circulating among North American dogs, Clinical and Vaccine Immunology, 15(4)(2008),

707-712, https://doi.org/10.1128/cvi.00005-08

[28] Keawcharoen. J., Theamboonlers. A., Jantaradsamee. P., Rungsipipat .A., Poovorawan. Y. \& Oraveerakul. K., Nucleotide sequence analysis of nucleocapsid protein gene of canine distemper virus isolates in Thailand, Vet Microbiol, 105(2)(2005), 137-142, https://doi.org/10.1016/j.vetmic.2004.10.011

[29] Krakowka. S., Olsen. RG., Axthelm. MK., Rice. J. \& Winters. K., Canine parvovirus infection potentiates canine distemper encephalitis attributable to modified live-virus vaccine, $J \mathrm{Am}$ Vet Med Assoc, 180(2)(1982), 137-9.

[30] Kumar. S., Stecher. G., Li. M., Knyaz. C. \& Tamura. K., MEGA X: Molecular Evolutionary Genetics Analysis across Computing Platforms, Mol Biol Evol, 35(6)(2018),1547-1549, https://doi.org/10.1093/molbev/msy096

[31] Lan. NT., Yamaguchi. R., Inomata. A., Furuya. Y., Uchida. K., Sugano. S. \& Tateyama. S., Comparative analyses of canine distemper viral isolates from 
clinical cases of canine distemper in vaccinated dogs, Vet Microbiol 115(1-3)(2006),32-42, https://doi.org/10.1016/j.vetmic.2006.01.010

[32] Latha. D., Srinivasan. S., Thirunavukkarasu. P., Gunaselan. L., Ramadass. P. \& Narayanan. R., Assessment of canine distemper virus infection in vaccinated and unvaccinated dogs, (2007)

[33] Lednicky. JA., Dubach. J., Kinsel. MJ., Meehan. TP., Bocchetta. M., Hungerford. LL., Sarich. NA., Witecki. KE, Braid. MD \& Pedrak. C., Genetically distant American Canine distemper virus lineages have recently caused epizootics with somewhat different characteristics in raccoons living around a large suburban zoo in the USA, Virology journal, 1(1)(2004),2.

[34] Li. W., Li T, Liu .Y., Gao. Y., Yang. S., Feng. N., Sun. H., Wang. S., Wang. L., Bu. Z. \& Xia. X., Genetic characterization of an isolate of canine distemper virus from a Tibetan Mastiff in China, Virus Genes, 49(1) (2014), 45-57, https://doi.org/10.1007/s11262-014-1062-z

[35] Litster. AL., Pressler. B., Volpe. A. \& Dubovi. E., Accuracy of a point-of-care ELISA test kit for predicting the presence of protective canine parvovirus and canine distemper virus antibody concentrations in dogs, Vet J, 193(2)(2012), 363366, https://doi.org/10.1016/j.tvjl.2012.01.027

[36] Marinho R, dos Anjos. ST., Melazzo. C., Machado. M., Zanini. F., Brolo. D., França. RT., Varaschine. L. \& Adriel. R., A hematologic and electrophoretic study in puppies vaccinated against canine distemper virus and canine parvovirus, Acta Scientiae Veterinariae, 40(1)(2012).

[37] Martella. V., Blixenkrone-Moller. M., Elia. G., Lucente. MS., Cirone. F., Decaro. N., Nielsen. L., Banyai. K., Carmichael. LE. \& Buonavoglia. C., Lights and shades on an historical vaccine canine distemper virus, the Rockborn strain, Vaccine, 29(6)(2011), 1222-1227, https://doi.org/10.1016/j.vaccine.2010.12.001

[38] Martella. V., Cavalli. A., Decaro. N., Elia. G., Desario. C., Campolo. M., Bozzo. G., Tarsitano. E. \& Buonavoglia. C., Immunogenicity of an intranasally administered modified live canine parvovirus type $2 \mathrm{~b}$ vaccine in pups with maternally derived antibodies, Clin Diagn Lab Immunol 12(10)(2005), 1243-1245, https://doi.org/10.1128/cdli.12.10.1243-1245.2005

[39] McCandlish. IA., Cornwell. HJ., Thompson. H., Nash. AS., Lowe. CM., Distemper encephalitis in pups after vaccination of the dam, Vet Rec, 130(2)(1992), https://doi.org/10.1136/vr.130.2.27

[40] McInnes. EF., Burroughs. RE. \& Duncan. NM., Possible vaccine-induced canine distemper in a South American bush dog (Speothos venaticus), J Wildl Dis, 28(4)(1992), 614-617, https://doi.org/10.7589/0090-3558-28.4.614

[41] McWilliam. H., Li. W., Uludag. M., Squizzato. S., Park. YM., Buso. N., Cowley. AP. \& Lopez. R., Analysis Tool Web Services from the EMBL-EBI, Nucleic Acids Res, 41(W1) (2013), W597-600, https://doi.org/10.1093/nar/gkt376
[42] Miranda. C. \& Thompson. G., Canine parvovirus in vaccinated dogs: a field study, Vet Rec, 178(16)(2016), https://doi.org/10.1136/vr.103508

[43] Miyamoto. T., Taura. Y., Une. S., Yoshitake. M., Nakama. S. \& Watanabe. S., (1992) Changes in blastogenic responses of lymphocytes and delayed type hypersensitivity responses after vaccination in dogs, $J$ Vet Med Sci, 54(5), 945-950, https://doi.org/10.1292/jvms.54.945

[44] Pardo. ID., Johnson. GC. \& Kleiboeker. SB., Phylogenetic characterization of canine distemper viruses detected in naturally infected dogs in North America, J Clin Microbiol, 43(10)(2005), 5009-5017, https://doi.org/10.1128/jcm.43.10.50095017.2005

[45] Phillips. TR. \& Schultz. RD., Failure of vaccine or virulent strains of canine parvovirus to induce immunosuppressive effects on the immune system of the dog, Viral Immunol, 1(2)(1987),135-144, https://doi.org/10.1089/vim.1987.1.135

[46] Pratelli. A., Cavalli. A., Martella. V., Tempesta. M., Decaro. N., Carmichael. LE. \& Buonavoglia. C., Canine parvovirus (CPV) vaccination: comparison of neutralizing antibody responses in pups after inoculation with CPV2 or CPV2b modified live virus vaccine, Clin Diagn Lab Immunol, 8(3)(2001) 612-615, https://doi.org/10.1128/cdli.8.3.612-615.2001

[47] Prittie. J., Canine parvoviral enteritis: a review of diagnosis, management, and prevention, Journal of Veterinary Emergency and Critical Care, 14(3)(2004), 167-176, https://doi.org/10.1111/j.1534-6935.2004.04020.x

[48] Ramadass. P., Latha. D., Dot enzyme immunoassay for detection of canine distemper virus, Indian Veterinary Journal (India), (2001)

[49] Ramdas. HN., Molecular Characterization of Vp2 Gene of Canine Parvo Virus From Vaccinal Strains. (Master of Veterinary Science), Anand Agricultural University, College of Veterinary Science and Animal Husbandry, (2011)

[50] Reed. LJ., Muench. H., A simple method of estimating fifty per cent endpoints, American journal of epidemiology, 27(3)(1938), 493-497, https://doi.org/10.1093/oxfordjournals.aje.a118408

[51] Rikula. UK., Canine distemper in Finland: vaccination and epidemiology. (ACADEMIC DISSERTATION), Department of Production Animal Medicine, Faculty of Veterinary Medicine, University of Helsinki, Helsinki, Finland, (2008)

[52] Riley. MC. \& Wilkes. RP., Sequencing of emerging canine distemper virus strain reveals new distinct genetic lineage in the United States associated with disease in wildlife and domestic canine populations, Virol J, 12(1) (2015), 219, https://doi.org/10.1186/s12985-015-0445-7

[53] Rzeżutka. A. \& Mizak. B., Sequence analysis of the fragment of the phosphoprotein gene of Polish distemper virus isolates, Archives of virology, 148(8)(2003),

1623-1631, https://doi.org/10.1007/s00705-003-0128-3 
[54] Saitou. N. \& Nei. M., The neighbor-joining method: a new method for reconstructing phylogenetic trees, Mol Biol Evol, 4(4)(1987),406-25.

[55] Salem. NY. \& Farag. HS., Clinical, Hematologic, and Molecular Findings in Naturally Occurring Babesia canis vogeli in Egyptian Dogs, Vet Med Int, (2014), 270345.

[56] Schalm. O., Jaim. N. \& Carroll. E., Veterinary Haematology. 3rd (ed.) Lea. And Febiger, Philadelphia, USA, (1975)

[57] Shackelton. LA., Parrish. CR., Truyen. U. \& Holmes. EC., High rate of viral evolution associated with the emergence of carnivore parvovirus, Proc Natl Acad Sci U S A, 102(2)(2005), 379-384, https://doi.org/10.1073/pnas.0406765102

[58] Singh. K., Osman. OA., El Cicy. IF. \& Baz. TI., Colostral Transfer of Rinderpest Neutralizing Antibody to Offspring of Våccinated Dams, Canadian journal of comparative medicine and veterinary science, 31(11)(1967), 295.

[59] Soliman. AF., Attyat. M. K. \& Albehwar.A.M., The efficacy of Dot Elisa Kits for estimation of canine parvo immunoglobulin, Egyptian vet. Med. Assoc 74(2)(2014), 237 -44.

[60] SPSS, for Windows. Chicago, IL: SPSS Inc, (2006)

[61] Strasser. A., May. B., Teltscher. A., Wistrela. E. \& Niedermuller. H., Immune modulation following immunization with polyvalent vaccines in dogs, Vet Immunol Immunopathol, 94(3-4)(2003), 113121, https://doi.org/10.1016/s0165-2427(03)000862

[62] Swati, Deka. D, Uppal. SK. \& Verma. R., Isolation and phylogenetic characterization of Canine distemper virus from India, Virusdisease, 26(3)(2015), 133-140, https://doi.org/10.1007/s13337-015-0256-x

[63] Sykes. JE., Appendix - Vaccination Schedules for Dogs and Cats. In J. E. Sykes (Ed.), Canine and Feline Infectious Diseases (pp. 893-900). Saint Louis: W.B. Saunders, (2014)

[64] Truyen. U., Steinel. A., Bruckner. L., Lutz. H. \& Mostl. K., Distribution of antigen types of canine parvovirus in Switzerland, Austria and Germany, Schweiz Arch Tierheilkd, 142(3)(2000), 1151119,

[65] Uema. M., Ohashi. K., Wakasa. C. \& Kai. C., Phylogenetic and restriction fragment length polymorphism analyses of hemagglutinin (H) protein of canine distemper virus isolates from domestic dogs in Japan, Virus Res, 109(1)(2005), 59-63, https://doi.org/10.1016/j.virusres.2004.10.008

[66] Vigerust. DJ. \& Shepherd. VL., Virus glycosylation: role in virulence and immune interactions, Trends Microbiol, 15(5)(2007), 211-218, https://doi.org/10.1016/j.tim.2007.03.003

[67] Waner. T., Mazar. S., Nachmias. E., KerenKornblatt. E. \& Harrus. S., Evaluation of a dot ELISA kit for measuring immunoglobulin $M$ antibodies to canine parvovirus and distemper virus, Vet Rec, 152(19)(2003) 588-591, https://doi.org/10.1136/vr.152.19.588

[68] Waner. T., Naveh. A., Meir. NSB., Babichev. Z. \& Carmichael. L., Assessment of immunization response to caninedistemper virus vaccination in puppies using a clinic-based enzyme-linked immunosorbant assay, The Veterinary Journal, 155(2) (1998), 171-175 https://doi.org/10.1016/s1090-0233(98)80013-0

[69] Waner. T., Naveh. A., Wudovsky. I. \& Carmichael. L., Assessment of maternal antibody decay and response to canine parvovirus vaccination using a clinic-based enzyme-linked immunosorbent assay, Journal of veterinary diagnostic investigation, 8(4)(1996), 427-432, https://doi.org/10.1177/104063879600800404

[70] Willesen. JL., Jensen. AL., Kristensen. AT. \& Koch. J. Haematological and biochemical changes in dogs naturally infected with Angiostrongylus vasorum before and after treatment, Vet J, 180(1)(2009), 106-111, https://doi.org/10.1016/j.tvjl.2007.10.018

[71] Woldemeskel. M., Liggett. A., Ilha. M., Saliki. JT. \& Johnson. LP., Canine parvovirus-2b-associated erythema multiforme in a litter of English Setter dogs, Journal of veterinary diagnostic investigation, 23(3)(2011), 576-580, https://doi.org/10.1177/1040638711403429

[72] Zhao. J., Yan. X. \& Wu. W., Genetic variations and cellular receptors of Canine distemper virus--a review, Wei Sheng Wu Xue Bao, 48(7)(2008), 986-91.

[73] Zhao. J., Zhang. H., Bai. X., Martella. V., Hu. B., Sun. Y., Zhu. C., Zhang. L., Liu. H., Xu. S., Shao. X., Wu. W., Yan. X., Emergence of canine distemper virus strains with two amino acid substitutions in the haemagglutinin protein, detected from vaccinated carnivores in North-Eastern China in 2012-2013, Vet J, 200(1)(2014), 191-194, https://doi.org/10.1016/j.tvjl.2014.01.028 